\title{
Progress of the V4 Countries towards the EU's Energy and Climate Targets in the Context of Energy Security Improvement
}

\author{
Agnieszka Pach-Gurgul, Marta Ulbrych
}

\begin{abstract}
A B S T R A C T
Objective: The aim of this article is to conduct an empirical verification of progress in implementing the provisions of the EU Energy Package and to assess this process in the context of opportunities to boost the energy security of the V4 countries by more efficient energy consumption, using renewable energy and reducing emission of greenhouse gases. Research Design \& Methods: The diagnosis is based on the determination of a taxonomic measure using Hellwig's multidimensional comparative analysis method. Then, a linear grouping of objects is used on the basis of changes in the value of indicators in order to prepare a ranking of the EU member states.
\end{abstract}

Findings: Considering all EU member countries, the V4 economies record an average rating in the implementation of the energy and climate framework. Slovakia and Hungary are ranked the highest, Poland and the Czech Republic - the lowest.

Implications \& Recommendations: The research and discussion might be interesting for policymakers and may have an application value for institutions dealing with energy security and climate policy in the V4 countries.

Contribution \& Value Added: The study measures progress in the implementation of the energy and climate package in the context of its importance for the energy security of the V4 economies. The work also presents the results of our own research based on taxonomic methods. Using a synthetic variable, a ranking of the EU members and their classification is elaborated according to the level of the indicators studied.

\begin{tabular}{ll}
\hline Article type: & research article \\
Keywords: & The EU's Energy Package; energy security; Visegrad group countries \\
JEL codes: & K32, Q56
\end{tabular}

Received: 30 August 2018 Revised: 2 March 2019 Accepted: 4 March 2019

\section{Suggested citation:}

Pach-Gurgul, A., \& Ulbrych, M. (2019). Progress of V4 Countries towards the EU's Climate and Energy Targets in the Context of the Energy Supply Security Improvement. Entrepreneurial Business and Economics Review, 7(2), 175-197. https://doi.org/10.15678/EBER.2019.070210 


\section{INTRODUCTION}

The countries of the European Union are striving to diversify the structure of their energy sources by looking for solutions which would be both economically efficient and environmentally friendly. The European Union is undertaking a number of initiatives to promote the modernisation of the energy sector, a fact that is manifested in numerous directives regulating the functioning of the sector. This study focuses on the climate and energy framework adopted in 2008, which comprises a body of binding regulations aimed at carrying out tasks related to climate and energy challenges by 2020 . The initiative concentrates on three key objectives, including the reduction of greenhouse gas emissions by $20 \%$, an increase of renewable sources in the EU energy balance by $20 \%$, and a growth of energy efficiency by $20 \%$ (20-20-20). The objectives, defined in such a way, are based on the three pillars of the EU energy policy, i.e. energy security, competitive markets, and sustainable development.

This research is focused primarily on the dimension of energy security which, in a longterm perspective, deals with timely investments to supply energy in line with economic developments and sustainable environmental needs (International Energy Agency: IEA, 2019). Hence, rationalising the consumption of energy and improving the energy efficiency of the generation and transmission systems are to provide a guarantee of strengthening the energy security of the European economies (Simanaviciene, Volochovic, \& Cibinskiene, 2016). The need to accomplish these tasks is clear in the context of a general downward trend in primary energy production - in 2016, the European Union countries produced $14.7 \%$ less energy than a decade before. Decreasing production of primary energy results in a situation where meeting the EU demand increasingly depends on energy imports. This dependence grew from 40\% of energy gross consumption in 1990, to 53.6\% in 2016 (Eurostat, t2020_rd320). Naturally, the conditions of the member countries in this respect are varied; nevertheless, security of energy supply poses a significant problem for all economies, including the Visegrad Group countries (V4) (Czech, 2017). A study conducted by the Kosciuszko Institute in 2011 contains a comparative analysis of the V4 countries' energy security and indicates that these countries experience similar energy related problems which stem from being dependent on import resources from one direction, apparent diversification, illusory coal-based energy security and the need to significantly reduce $\mathrm{CO}_{2}$ emissions (Kovács et al., 2011). Currently, Slovakia and Hungary, despite a reduction in recent years, are economies whose dependence on energy imports is above average compared to the EU. On the other hand, Poland and the Czech Republic are relatively less dependent, and yet, their dependence is growing.

The adopted energy targets should contribute to making the EU less dependent on energy imports as the consumption of fossil fuels is reduced to limit greenhouse emissions (Siddi, 2016, p. 135) and the share of renewable energy sources is increased (Slaboch \& Hálová, 2016). Assuming that the 2020 targets are compatible with an improvement in the V4 economies' energy security, the main aims of the study is to diagnose the degree of 2020-20 strategy realisation. Moreover, this article is a chance to fill a gap in research into the energy and climate package in the context of its significance for the energy security of the Visegrad Group countries, which gives an innovative character to the current studies. 
The grounds for the choice of research problem allowed us to formulate the following hypothesis: a systematic execution of the objectives of the package will allow the V4 countries to increase the level of energy security in their economies by means of rationalising their energy consumption, and also by increasing the share of renewable energy sources in their total energy consumption and by reducing the emission of greenhouse gases. The objective of this article is to evaluate the degree of implementation of the 20-20-20 objectives by the V4 countries, and to assess the possibility of comparing the achievements of these countries in this area. This is meant to result in formulating conclusions with an applicable value for institutions involved in energy security, energy or climate policy in these countries.

In order to rank the implementation of the strategy as adopted in the EU member countries, Hellwig's multivariate analysis method is used. Hellwig's taxonomic development measure synthesises information in a sequence of diagnostic variables and attributes aggregate one measure to the analysed phenomenon. Indicators related to energy use, the share of renewable sources and emissions of greenhouse gases have been considered as key factors to monitoring changes. The research is based on an analysis of the EU source documentation and a statistical study of the analysed phenomena.

The structure of this article is organised as follows: the first section presents a literature review and a development of energy security theory. Then the essence of the energy and climate package in the context of the energy security of the V4 countries is explained. In section 2, the procedure for the selection of diagnostic variables, the taxonomic method and a preliminary analysis of the statistical information collected are presented. In the next, third section, the focus is on a presentation of the empirical results of the study, and subsequently, conclusions and implications are developed.

\section{LITERATURE REVIEW}

In Abraham Maslow's theory of needs, the second level in the fulfilment hierarchy, immediately above physiological needs, is occupied by safety needs. Once these are satisfied, a human being thinks about the fulfilment of higher needs (Mitchell \& Moudgill, 1976). In safety typology, energy security is regarded as a very important type of safety, making up an essential constituent of a generally understood safety defined as the national security of a country (Chester, 2010; Dyer \& Trombetta, 2013).

The source literature presents a variety of definitions of energy security. This multitude of definitions is continually evolving with regards to the changing character of safety as an entity, condition, process or phenomenon. The literature on the subject contains a debate about both the object and the subject of safety. Safety can be defined with regards to an individual, a local and regional community, a state and the international community. Many researchers, such as Kruyt et al., (2009), Winzer (2012) and Narula and Reddy (2015) agree that no consensus exists around one complete and universal definition of energy security, as it is an equivocal, multifaceted dynamic term. Currently, it is closely connected with the policy of sustainable development, economic factors, the development of energy markets and socio-economic changes in IT technologies or in transport, facts which are clearly stressed in the research by Radovanović, Filipović and Pavlovićc (2017).

The simplest definition refers to energy security as: 'the availability of sufficient supplies at an affordable price' (Yergin, 2006). The constituents of such security comprise: market integration (crude oil, gas, electricity), diversification of resources, safety margin 
(e.g. in a form of the reserves of energy raw materials). A detailed definition covers, with its scope, 'the availability of energy at any time, in various forms, in sufficient quantity and at a reasonable price and/or an affordable price' (Månsson et al. 2014; NygaŁukaszewska \& Chilimoniuk-Przeździecka, 2017). Energy security can also be defined as 'the availability of adequate energy at an affordable and reliable price, necessary both from the technological point of view and also from the perspectives of human security' (Wang et al., 2018; Sovacool, 2013, Augutis et al., 2012).

In practice, energy security concerns many aspects, not only of a strategic and geopolitical character, referring first of all to the effects of the dependence on the import of raw materials and those resources of which an entity is in possession (Chalvatzis \& loannidis, 2017; Kiriyama \& Kajikawa, 2014; Semenenko, 2016; Gunnar Austvik, 2016), but also to other aspects (Dannreuhter, 2017; Jamasb \& Pollit, 2008; Xia et al., 2011; Zajączkowska, 2016), namely:

- economic - for a consumer, this means the ability to purchase necessary energy at an affordable price,

- ecological - concerning respect for the natural environment, among other things, by means of the limitation of the use of conventional fuels, which is meant to reduce the emission of $\mathrm{CO}_{2}$, or the use of new environment-friendly technologies, e.g. CCS (carbon capture and storage),

- infrastructural - as the condition of infrastructure, the lack of financing and investments into infrastructure have a direct impact on the energy security of a given country.

According to the IEA, energy security in practice should be perceived as a problem pertaining to risk management, i.e. 'the reduction of risk and consequences of disruptions to an acceptable level' (IEA, 2007). The condition of energy security may be described as the uninterrupted/continual possibility to access energy at an affordable price, taking account, at the same time, of issues related to the protection of the natural environment. The IEA differentiates between energy security in a long-term and short-term context. Energy security in a long-term context is strongly connected with planned or executed investments (into infrastructure in particular) which are meant to facilitate the energy supply, and, at the same time, energy security is strongly correlated with the economic development of a given country and the needs of the natural environment. Short-term energy security, then, in the view of the IEA, is seen as the capability of a prompt reaction of the energy system to sudden changes in energy demand and supply. Such an understanding of energy security is also referred to in various academic publications and research projects (Sovacool et al., 2011, Cherp \& Jewell, 2011). Thus, it can be observed that a number of research projects emphasise an interdisciplinary approach to energy security (Månsson, 2014; Cipollaro \& Lomonaco, 2016; Löschel, Moslener, \& Rübbelke, 2010; Kapustová, Kapusta, \& Bielik, 2018).

The problem of energy security was treated as a political issue for many years, with lesser significance for the economy of a given country. After the end of WWII, the general accessibility of energy raw materials and their relatively low prices resulted in the fact that the problem of supplying economies with energy was not perceived in strategic terms. Yet, such events as the oil crisis of 1973, the end of the cold war, or the sudden increase in the prices of energy raw materials resulted in a change of approach towards the theory of energy security and heated up the debate on this subject, in particular in the context of crude oil substitutes or the diversification of the methods of its acquisition, which has been observed by Proskuryakova (2011) or Markandya and Pemberton (2010). However, even 
so this issue was still not a priority in the policy of the majority of world countries. It was only the record-breaking prices of crude oil in the summer of 2008, the second war in Iraq, the problem of global warming, the world economic crisis and its consequences for the prices of raw materials and for investments in the energy sector that brought the debate on energy security back onto the table. It was then that priority and strategic significance for the functioning of particular states was attributed to the above issue, a fact that is confirmed in the studies by Goldthau (2011), and also Zhou et al. (2018).

With the progress of time, the subject of energy security has become essential for the European Union, which is currently the world's largest importer of primary energy, as more than half of the energy consumed in the EU (53.6\%) is imported (European Commission, 2018). At the same time, this is an import from a relatively small number of suppliers which implies a potential threat to energy security. The fact that about $30 \%$ of each of the key energy carriers today (crude oil, natural gas or coal) imported into the EU, is purchased from Russia (European Commission, 2018) is especially disadvantageous. Unfortunately, this dependence has persisted for many years, a fact which is observed in many research analyses (Costantini et al., 2006; Jääskeläinen et al., 2018). The breakthrough in the European Union in the perception of energy security came with the gas crises between Russia and Ukraine in January 2006, and in particular, in January 2009. These conflicts delineated the importance of the energy security of the EU and the threats which existed in energy supply and distribution. As a result of the crisis in 2009, gas supply to a total 300 million cubic meters per day was cut off for 14 days, and as a result, in the period between 6th and 20th January, the EU countries were deprived of $20 \%$ of their gas, a fact which had grave economic consequences. The loss sustained by the EU countries was estimated to be 1.6 billion EUR (Lee, 2017). Many researchers point out that concerns about energy security began to grow even more in the face of the new political conflict between Russia and Ukraine in 2014 (Van de Graaf \& Colgan, 2017; Goldthau \& Boersma, 2014).

As a result of the gas crises, the Visegrad Group countries also sustained a lot of harm. Their sense of energy security was strongly shaken. The source literature and academic analyses point to the fact that these countries still have a poorly developed gas pipeline infrastructure in directions other than east-west and they are strongly dependent on the import of Russian gas, which is supplied through Ukraine (Gálová, 2013). These countries experienced significant disturbances in the supply of gas during that period. Only the Czech Republic imported some amount of gas through the system of the German gas supply network, which compensated for the shortages in Russian supplies. All the other countries could only rely on their strategic reserves. The country that suffered the most as a result of the supply cut-off was Slovakia (Muller-Kraenner, 2007). It was for the first time in its history that it was completely cut off from external gas supplies. Poland did not receive $80 \%$ of its planned supplies and Hungary $60 \%$.

This is why, over the course of time, the EU leaders have undertaken efforts aimed at the limitation of the dependence on imports of raw materials and at strengthening the energy security of the EU in all other aspects. This is why actions were initiated aimed at a broadly defined diversification of the new suppliers of energy raw materials, such as Canada, the USA or China. At the same time, solutions influencing the EU energy security in many aspects have been sought (Marquina, 2008). This was the context of the preparation of the energy and climate package, not only in this strategic and political aspect, but 
also in an economic, ecological and infrastructural one, a fact which is also pointed out in the studies by Skjærseth (2013), Helm, (2014) and also Christa Uusi-Rauva (2010).

\section{The Essence of the Energy and Climate Package in the Context of the Energy Situation of the Visegrad Group Countries}

On 23rd January 2008, the European Commission presented the energy and climate package, which constitutes a collection of objectives and goals which are intended to be achieved by 2020 by the European Union in its energy and climate policy. This Package is known as $3 \times 20 \%$ or $20-20-20$ by 2020 , with its main objectives being:

1. An increase of the share of the energy obtained from renewable sources of energy (RSE) to $20 \%$ in the total energy balance of the European Union by 2020.

2. A limitation of the primary energy consumption in the European Union by $20 \%$ in comparison with the prognosis made for 2020, and presented in 2005.

3. A reduction of $\mathrm{CO}_{2}$ emission by $20 \%$, in comparison with the level of emissions from 1990 .

This undertaking put an obligation on the member states to implement the main Directives in this respect (European Commission, 2012; European Commission, 2013; European Parliament and the Council of the European Union, 2009), and thus to amend their national energy policies, which is by no means an easy task due to the diversity of the energy cultures of these countries, a fact which is pointed out in the research of Stephenson et al. (2010), Love, Rupp and Strauss (2013), Tapio et al. (2007), and Campbell (2002). The objectives of the energy and climate package have become so significant that they were also confirmed in the 'Europe 2020' Strategy (European Commission, 2010). The literature on this subject shows a dispute as to whether this document really makes any contribution to the energy security of the EU (Henriksen, Hussey, \& Holm, 2011), or whether it rather implies unnecessary costs for these countries and should rather be simply amended (McKillop, 2012). The package defines the main objectives for the entire European Union: $3 \times 20 \%$ by 2020 , consisting of individual objectives concerning the share of renewable energy in their energy mixes and also the reduction of $\mathrm{CO}_{2}$ emission and a decrease in the primary or final energy consumption. These objectives vary between the member states with regards to the diversity of their raw material supplies, their national energy mixes, the energy consumption level of their industries, their GDP per capita, their national energy policy, etc. (Pach-Gurgul, 2016).

The execution of the provisions of the energy and climate package poses a significant challenge for all the EU countries. There are many academic and research papers concerning the execution of the energy and climate package by specific EU member states, such as Germany (Eikeland, 2014) or the Netherlands (Gulbrandsen, Skjærseth, \& Birger, 2014), or discussing the subject in the context of their economic growth (Smiech \& Papież, 2014). There is, however, no research concerning the execution of the objectives of the energy and climate package by the Visegrad Group countries, which have a very specific energy situation, especially in the context of their energy security which was the main motivation for the Authors of this study to take up this subject.

These countries, after the Second World War, found themselves under the hegemony of the Soviet Union, with very strong connections to that country, resulting from economic treaties and military pacts. The common historic heritage of these countries with centrally 
planned economies resulted in the fact that, in spite of the existing differences in the national, ethnic and cultural spheres, their economies were very similar to one another. This fact also had a great influence on their industries and the direction of their development (Ulbrych, 2018). The Central European countries invested in energy-consuming and high-carbon emitting heavy industry, making up a specific energy culture based on the accessibility of cheap energy raw materials - coal, crude oils and natural gas - traded at preferential prices within the soviet bloc (Fitzmaurice, 1998). Cheap raw materials and final energy, treated as a common public good, the provision of which was the responsibility of the state, did not foster energy saving and even contributed to its waste. The use of fossil hydrocarbons in energy production resulted in high carbon emisiveness. All these factors and circumstances contributed to the creation of an energy situation of the Visegrad Group countries completely different from that of other EU countries, and this difference still persists. The most sensitive issue is the dependence of the V4 countries on the import of raw materials from one source only, namely Russia, on account of its geographic closeness, as observed in the studies of Aalto (2016), Smith (2008), Finon and Locatelli (2008).

All these circumstances result in the fact that the extent of the heavy historic heritage of this group of countries renders the execution of the energy and climate package extremely difficult. However, the realisation of this package may indirectly contribute to a positive impact on the level of energy security by means of increasing the share of renewable sources of energy, and thus decreasing the dependence on imported energy raw materials, enlarging their energy efficiency, reducing greenhouse gas emissions; all of which, from the point of view of the protection of the natural environment, makes up an issue of gross significance.

\section{MATERIAL AND METHODS}

The research procedure was subordinated to the adopted hypothesis, which assumes that the systematic implementation of the $20-20-20$ requirements will allow the $\mathrm{V} 4$ countries to increase the level of energy security of their economies by rationalising energy consumption, increasing the share of renewable energy in total energy consumption and reducing greenhouse gas emissions. Research into climate and energy implementation progress has been carried out for all $28 \mathrm{EU}$ member countries for the years 2005-2016 and the data on which the research was based comes from the Internet databases of the European Statistical Office (Eurostat). For the empirical verification of the degree of achievement of the 2020-20 objectives by the $\mathrm{V} 4$ countries, the method of multivariate comparative analysis was selected, which also allows the possibility of organising objects and comparing the economies analysed with other EU member states. The study is based on the determination of a taxonomic measure using the Hellwig's method, applied to develop the ranking of objects described in a multidimensional space of features, while taking certain ordering criteria into consideration. For the linear ordering of objects described by many diagnostic variables, a synthetic indicator of development is calculated (Gałecka \& Smolny, 2018, p. 41).

\section{Selection of Input Variables and Their Time Course}

After the analysis of several methodological approaches and the verification of the suitability and accessibility of statistical data, the Authors decided to base their research on a classical approach, which takes into consideration the following variables: 
- in the area of the greenhouse gas emissions reduction by $20 \%$ : 'greenhouse gas emissions, base year 1990'. This variable is presented as a percentage in reference to the year 1990 and is negatively correlated with the explained variable, i.e. it is a destimulant;

- in the area of the RSE share increase in the EU energy balance by $20 \%$ : 'share of renewable energy in gross final energy consumption'. The feature being analysed has the characteristics of a stimulant;

- in relation to the energy efficiency increase by $20 \%$ : 'primary energy consumption'. The EU aims to attain consumption at the level of 1483 million tonnes in 2020, which results from a reduction of consumption by $20 \%$ compared with predictions. Therefore, the forecast for 2020 was calculated in relation to 2005 , then, the consumption was divided by this forecast and so the objective to be reached is $80 \%$. Thus, an increase in the explanatory variable value leads to a decrease in the explained variable, so it is treated as a destimulant.

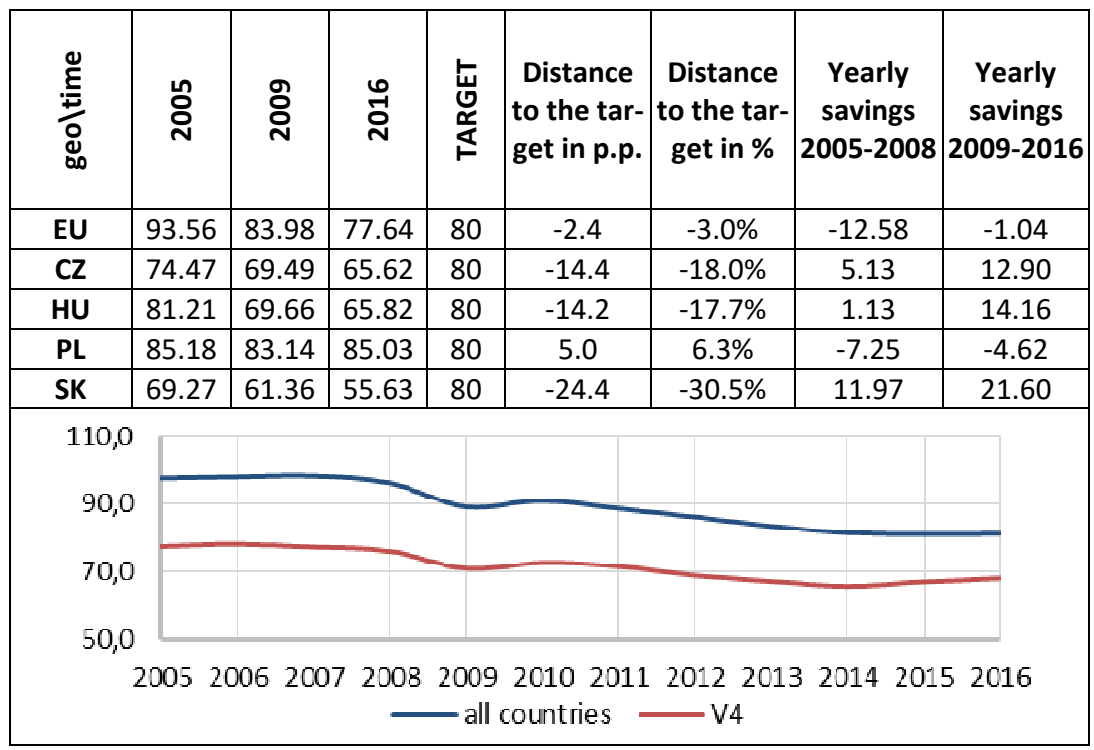

Figure 1. Greenhouse gas emissions, base year 1990 (\%) Source: own dataset based on Eurostat. (t2020_30).

Figure 1 presents greenhouse gas emissions in 2005, 2009, and 2016, as these years are important from the perspective of work on the climate and energy framework and its implementation (2005 and 2009); the last year concerns the most recent accessible data. The distance to the set target was calculated on the basis that values with a positive sign indicate what remains in order to achieve the target of $80 \%$ of 1990 use. The last two columns refer to the average annual savings in terms of a given feature. In the following years, in two time frames: 2005-2008 and 2009-2016, we calculated losses/savings, and then, the arithmetic mean. Since 2005 three V4 countries (the Czech Republic, Hungary, and Slovakia) have been systematically reducing greenhouse gas emissions from $74.9 \%$ to $62.4 \%$ of the 1990 level on average, thereby reaching the objective defined in the climate and energy framework. Poland, on the other hand, is still above the objective set due to a negative rate of annual savings in this respect. 


\begin{tabular}{|c|c|c|c|c|c|c|c|c|}
\hline$\frac{\stackrel{0}{E}}{\frac{E}{0}}$ & ¿̊ํ & ஜ્ণ & $\stackrel{0}{0}$ & $\begin{array}{l}\text { 㟧 } \\
\text { 安 }\end{array}$ & $\begin{array}{l}\text { Distance } \\
\text { to the tar- } \\
\text { get in p.p. }\end{array}$ & $\begin{array}{l}\text { Distance } \\
\text { to the tar- } \\
\text { get in \% }\end{array}$ & $\begin{array}{c}\text { Yearly } \\
\text { savings } \\
2005-2008\end{array}$ & $\begin{array}{c}\text { Yearly } \\
\text { savings } \\
2009-2016\end{array}$ \\
\hline EU & 9.0 & 12.4 & 17.0 & 20 & 3.0 & $15.0 \%$ & -9.98 & -5.26 \\
\hline $\mathrm{CZ}$ & 7.1 & 9.9 & 14.9 & 13 & -1.9 & $-14.6 \%$ & -5.23 & -0.15 \\
\hline $\mathrm{HU}$ & 6.9 & 11.7 & 14.2 & 13 & -1.2 & $-9.2 \%$ & -5.13 & 1.16 \\
\hline $\mathbf{P L}$ & 6.9 & 8.7 & 11.3 & 15 & 3.7 & $24.7 \%$ & -7.90 & -4.36 \\
\hline SK & 6.4 & 9.4 & 12.0 & 14 & 2.0 & $14.3 \%$ & -6.88 & -3.26 \\
\hline \multicolumn{7}{|c|}{25,0} & \multicolumn{2}{|c|}{20,0} \\
\hline \multicolumn{9}{|c|}{15,0} \\
\hline \multicolumn{9}{|c|}{10,0} \\
\hline \multicolumn{2}{|c|}{$\begin{array}{r}5,0,0 \\
5,0\end{array}$} & & & & & & & \\
\hline & & 200 & 2008 & 09 & $\begin{array}{l}20102011 \\
\text { cuunit ries }\end{array}$ & $\begin{array}{c}20122013 \\
-V 4\end{array}$ & 2014201 & 52016 \\
\hline
\end{tabular}

Figure 2. Share of renewable energy in gross final energy consumption (\%) Source: own dataset based on Eurostat. (t2020_31).

As far as the share of renewable energy in final energy consumption is concerned, the Czech Republic and Hungary have already exceeded their obligations (Figure 2). The interpretation of the result in reference to the distance of a given country to the adopted objective is analogical to that of Figure 1 - positive values refer to economies which need to improve their results. Poland is the furthest from its target, falling short by 3.7 pp. from reaching $15 \%$ of the RSE share. Slovakia is also $2 \mathrm{pp}$. below the target set at $14 \%$ of the consumption of final energy from renewable sources.

In the case of the third feature, describing progress in the area of energy efficiency improvement, the results of the V4 countries are similar to the average for all EU member countries, which suggests a consumption reduction to the level of $80 \%$ of use prediction for the year 2020. Analysing these changes in each country individually, we should emphasise that in 2016, Hungary, Poland, and Slovakia achieved better results than those intended by the strategy (Figure 3).

\section{The Analysis of Diagnostic Variables}

In order to analyse the degree of feature value differentiation, a coefficient of variation was used. The degree of diagnostic variable dispersion in reference to all EU countries is above $10 \%$, i.e. the variable is considerably different and statistically significant. Outliers can only be seen for the second variable, but the feature itself is low, and therefore, there is no need to apply the median (Table 1). However, in the case of the V4 economies, the features do not show undue variability, yet, it is high enough for Hellwig's method based on the average. 


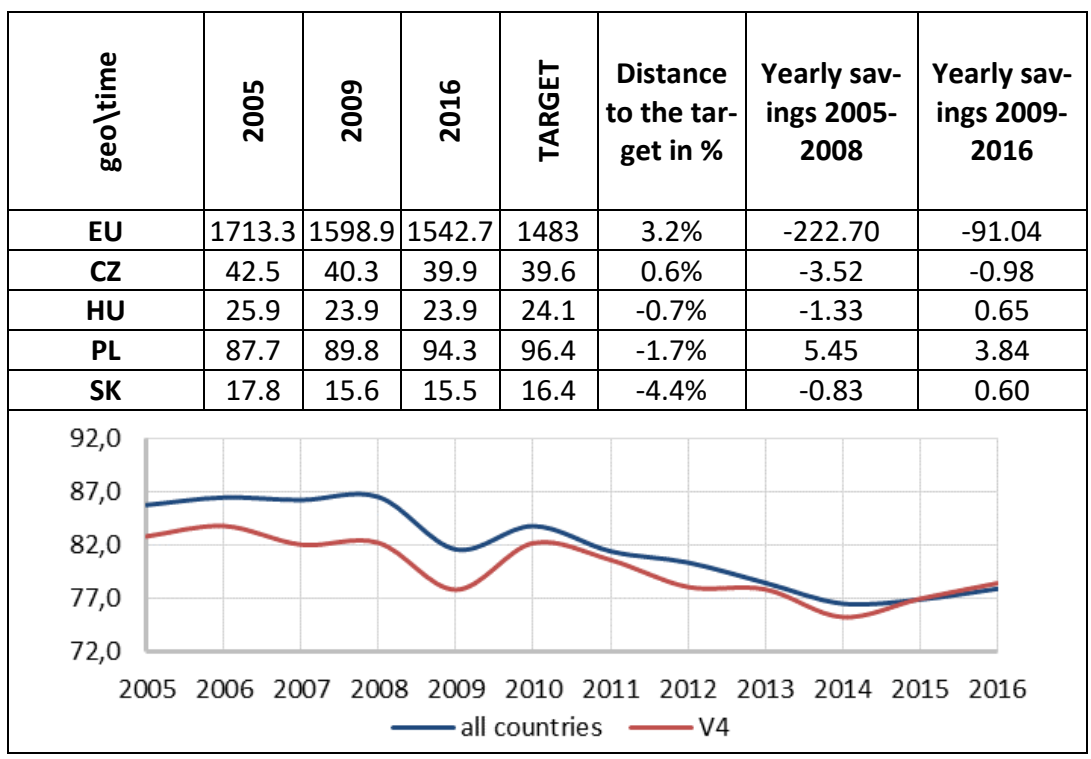

Figure 3. Primary energy consumption, (Mtoe) Source: own dataset based on Eurostat. (t2020_33).

An essential element of this research involves carrying out a multidimensional comparative analysis with the use of Z. Hellwig's taxonomical measure of development. A model was constructed according to the following procedure (Sojka, 2018, pp. 131-132):

- normalisation of diagnostic features on the basis of standardisation in order to fulfil the additive function postulate;

- determination of the pattern for variable stimulants and destimulants;

- after determination of the development pattern, the Euclidean distances between individual units of space and the model object $-d_{i 0}-$ were determined;

- calculation of the synthetic variable according to the formula: $q_{i}=1-d_{i 0} / d_{0}$, where $d_{0}$ is the sum of the arithmetic mean and the double of the standard variable outlier. The synthetic variable falls in the range $[0 ; 1]$, and $\max _{i}\left\{q_{i}\right\}$ stands for the best object;

- graphic illustration of the countries' positions.

Box plot graphs were used for the comparison of the shape of the data distribution for the aggregate variable. A graphic illustration of the observation dispersion for the cutoff years of the period being analysed is presented in Figure 4.

The length of the rectangle represents the inter-quartile range comprising the middle $50 \%$ of observations. It provides information on how the result for a given variable develops around the mean, i.e. it shows the number of lower/higher observations in the studied group than the average for the entire group. The analysis of the data collected in the figure shows that the variable took more different values in 2005 than in 2016, which indicates an improved similarity between some EU economies in the pursuit of the 20-20-20 goal. At the same time, however, there are more outliers in 2016, which results from the length of the 'whiskers'. At the beginning and at the end of the study, 
Table 1. Parameters of diagnostic variables in the years 2005-2016

\begin{tabular}{|c|c|c|c|c|c|c|c|c|c|c|c|c|c|}
\hline Indicator & $\begin{array}{l}\text { Average (a) } \\
\text { Coefficient of } \\
\text { variation (V) }\end{array}$ & 2005 & 2006 & 2007 & 2008 & 2009 & 2010 & 2011 & 2012 & 2013 & 2014 & 2015 & 2016 \\
\hline \multirow{4}{*}{$\begin{array}{c}\text { Greenhouse gas } \\
\text { emissions, base } \\
\text { year } 1990\end{array}$} & a-all & 97.6 & 98.0 & 98.3 & 96.2 & 89.2 & 91.1 & 88.7 & 86.2 & 83.5 & 81.5 & 81.0 & 81.2 \\
\hline & V-all & $32 \%$ & $31 \%$ & $31 \%$ & $32 \%$ & $33 \%$ & $31 \%$ & $31 \%$ & $32 \%$ & $30 \%$ & $31 \%$ & $30 \%$ & $31 \%$ \\
\hline & $a-V 4$ & 77.5 & 78.1 & 77.3 & 76.1 & 70.9 & 72.6 & 71.6 & 68.9 & 67.2 & 65.7 & 67.0 & 68.0 \\
\hline & V-V4 & $8 \%$ & $9 \%$ & $10 \%$ & $9 \%$ & $11 \%$ & $12 \%$ & $13 \%$ & $15 \%$ & $16 \%$ & $15 \%$ & $15 \%$ & $16 \%$ \\
\hline \multirow{3}{*}{$\begin{array}{c}\text { Share of } \\
\text { renewable energy } \\
\text { in gross final } \\
\text { energy } \\
\text { consumption } \\
\end{array}$} & a-all & 12.21 & 12.48 & 13.08 & 13.76 & 15.42 & 15.86 & 16.35 & 17.54 & 18.53 & 19.24 & 19.79 & 19.96 \\
\hline & $a-V 4$ & 6.8 & 7.1 & 7.8 & 8.2 & 9.9 & 10.4 & 11.4 & 12.4 & 12.9 & 13.2 & 13.5 & 13.1 \\
\hline & V-V4 & $4 \%$ & $5 \%$ & $8 \%$ & $6 \%$ & $11 \%$ & $14 \%$ & $13 \%$ & $16 \%$ & $18 \%$ & $12 \%$ & $10 \%$ & $11 \%$ \\
\hline \multirow{3}{*}{$\begin{array}{l}\text { Primary energy } \\
\text { consumption }\end{array}$} & a-all & 85.8 & 86.5 & 86.3 & 86.6 & 81.6 & 83.8 & 81.5 & 80.4 & 78.5 & 76.5 & 76.9 & 77.9 \\
\hline & V-all & $12 \%$ & $11 \%$ & $11 \%$ & $12 \%$ & $13 \%$ & $11 \%$ & $11 \%$ & $13 \%$ & $12 \%$ & $11 \%$ & $10 \%$ & $10 \%$ \\
\hline & $a-V 4$ & 82.9 & 83.8 & 82.1 & 82.2 & 77.8 & 82.2 & 80.6 & 78.1 & 77.9 & 75.3 & 77.0 & 78.5 \\
\hline
\end{tabular}

Source: own study. 
we can observe right-sided asymmetry (a skewness factor greater than zero), which is characteristic of a set where the majority of countries are doing worse than the average. On the other hand, in the middle years we can observe negative skewness, i.e. left-sided asymmetry, typical of a situation when most countries achieve better results than might be evident from the average for the entire EU.

The next stage of the research involves determining typological groups according to the synthetic measure level. Then, in order to enrich the analysis and address the hypothesis, the forecasts based on data from 2005-2016 is prepared.
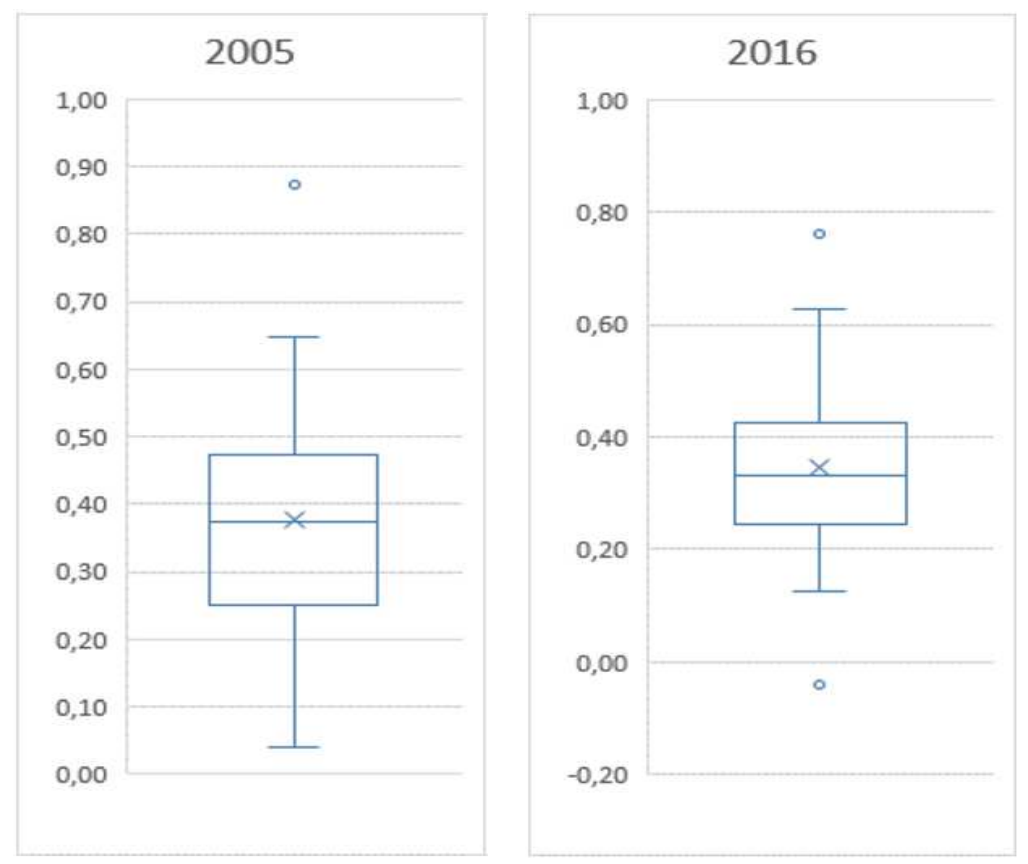

Figure 4. Distribution of the aggregate variable in 2005 and in 2016 Source: own study.

\section{RESULTS AND DISCUSSION}

Elaborating the synthetic variable, based on Hellwig's method, for each variable for every analysed country we calculated the distance from the pattern (i.e. from the value most favourable for the given variable - the highest for the stimulants, and the lowest for the destimulant). Then, the distance of a given country from the best country was determined on the basis of all the variables. The synthetic variable is expressed by the formula 1 minus the relative distance of a given country; therefore, the smaller the distance from the pattern, the better. The synthetic variable, based on features describing the progress in achieving the 2020-20 target, allows us to assess the progress of the V4 economies against the average for all EU countries. Figure 5 presents the course of this variable in the years 2005-2016. 


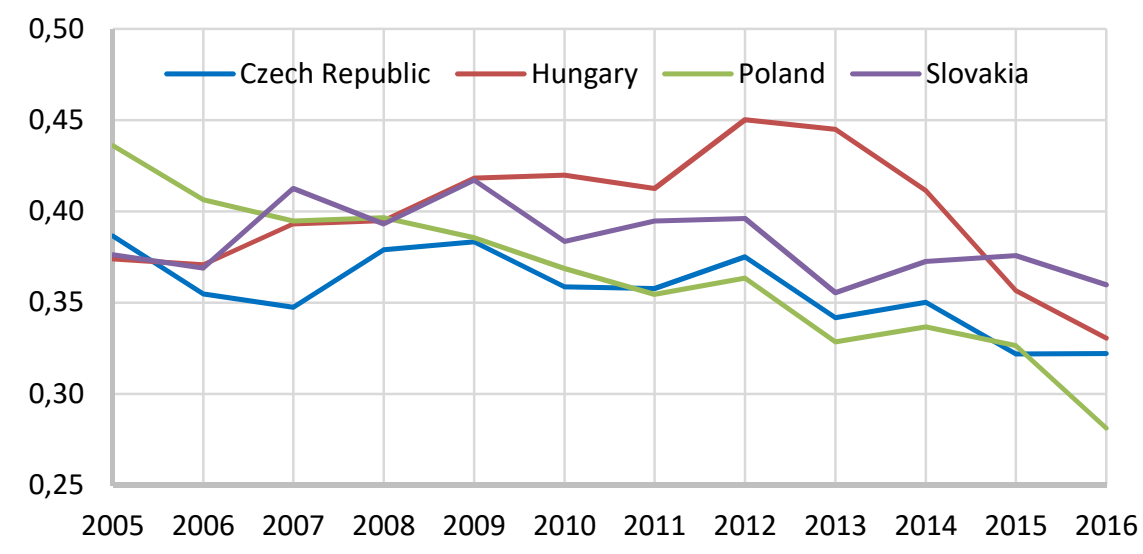

Figure 5. The value of the synthetic variable of the V4 countries in the years 2005-2016 Source: own study.

The analysis of the research results does not lead to optimistic conclusions for the V4 Group countries. In all cases, the aggregate measure in 2016 is lower in comparison with 2005. While in the case of Slovakia, Hungary, and the Czech Republic it is small $-0.02,0.05$ and 0.07, respectively, the result for Poland in 2016 was worse by 0.22 than in 2005 .

The ranking of countries presented in Table 2 is also useful in determining the V4 countries' position in the EU structure in terms of the phenomenon studied. The countries are listed alphabetically, and their positions in subsequent years are marked in blue or red. The colour intensity is correlated with a given country's position estimated on the basis of the synthetic variable. Therefore, the higher the value of the synthetic variable, the higher the position the country has in the ranking. The objects with the best result are marked with darker blue, the weakest economies are marked with red, and darker red suggests a worse result in the synthetic measure. Latvia, which takes the first place throughout the entire period analysed, is the undisputable leader. Interestingly, it did not have to make much effort because its targets for greenhouse gas emissions had already been achieved at the beginning. In the case of the other two variables, however, the differences were relatively small. Equally, Romania, which improved its result and moved up from the 5 th do the 2 nd position, occupies a high place in the ranking. A considerable positive change can be noticed in Greece (a difference of 11 positions), Italy (a difference of 9 positions), and Lithuania (a difference of 6 positions). Cyprus, last in the ranking, practically did not manage to reduce gas emissions at all, although it began from a very high level: twice the planned target. The situation with RSE looks much better in this country. In terms of the third variable, there is not much progress either, but at least the target is close. The largest drop, by 9 positions, can be seen in the case of Poland. Germany and France look relatively poor in this context - both countries went down by 5 positions.

In order to illustrate better the changes in the V4 countries' ranks in achieving the 2020-20 targets, Figure 6 was prepared. Despite a decrease in the synthetic variable value between the years 2005 and 2016, which was presented in Figure 5, Slovakia and Hungary improved their places in the ranking by two positions, which allowed them to become 
Table 2. Countries ranked according to Hellwig's method in the years 2005-2016

\begin{tabular}{|c|c|c|c|c|c|c|c|c|c|c|c|c|c|}
\hline Country & 2005 & 2006 & 2007 & 2008 & 2009 & 2010 & 2011 & 2012 & 2013 & 2014 & 2015 & 2016 & Country \\
\hline Belgium & 23 & 22 & 22 & 22 & 25 & 26 & 26 & 23 & 25 & 25 & 24 & 27 & Belgium \\
\hline Bulgaria & 11 & 15 & 14 & 14 & 9 & 10 & 16 & 13 & 8 & 15 & 18 & 14 & Bulgaria \\
\hline Czech Republic & 13 & 14 & 16 & 15 & 14 & 16 & 14 & 16 & 16 & 16 & 15 & 17 & Czech Republic \\
\hline Denmark & 10 & 16 & 13 & 8 & 10 & 14 & 9 & 8 & 9 & 6 & 8 & 7 & Denmark \\
\hline Germany & 16 & 18 & 17 & 17 & 18 & 18 & 17 & 18 & 20 & 20 & 20 & 21 & Germany \\
\hline Estonia & 3 & 3 & 4 & 5 & 3 & 3 & 3 & 4 & 6 & 7 & 6 & 5 & Estonia \\
\hline Ireland & 22 & 23 & 24 & 25 & 24 & 23 & 19 & 20 & 21 & 24 & 25 & 26 & Ireland \\
\hline Greece & 26 & 26 & 26 & 26 & 26 & 22 & 24 & 22 & 17 & 18 & 17 & 15 & Greece \\
\hline Spain & 25 & 24 & 25 & 24 & 21 & 19 & 21 & 21 & 19 & 19 & 22 & 22 & Spain \\
\hline France & 18 & 17 & 18 & 19 & 19 & 20 & 20 & 19 & 23 & 21 & 23 & 23 & France \\
\hline Croatia & 4 & 2 & 5 & 6 & 6 & 4 & 4 & 2 & 3 & 3 & 3 & 3 & Croatia \\
\hline Italy & 19 & 19 & 19 & 18 & 17 & 17 & 18 & 15 & 14 & 12 & 12 & 10 & Italy \\
\hline Cyprus & 27 & 27 & 27 & 27 & 27 & 27 & 27 & 27 & 27 & 27 & 27 & 28 & Cyprus \\
\hline Latvia & 1 & 1 & 1 & 1 & 1 & 1 & 1 & 1 & 1 & 1 & 1 & 1 & Latvia \\
\hline Lithuania & 12 & 10 & 15 & 16 & 16 & 5 & 5 & 6 & 4 & 4 & 5 & 6 & Lithuania \\
\hline Luxembourg & 20 & 20 & 20 & 20 & 20 & 21 & 23 & 24 & 22 & 22 & 19 & 20 & Luxembourg \\
\hline Hungary & 15 & 11 & 11 & 11 & 11 & 12 & 12 & 10 & 10 & 11 & 13 & 13 & Hungary \\
\hline Malta & 28 & 28 & 28 & 28 & 28 & 28 & 28 & 28 & 28 & 28 & 28 & 24 & Malta \\
\hline Netherlands & 21 & 21 & 21 & 21 & 23 & 25 & 25 & 26 & 26 & 26 & 26 & 25 & Netherlands \\
\hline Austria & 7 & 7 & 7 & 7 & 7 & 8 & 8 & 9 & 12 & 10 & 10 & 11 & Austria \\
\hline Poland & 9 & 9 & 10 & 10 & 13 & 15 & 15 & 17 & 18 & 17 & 14 & 18 & Poland \\
\hline Portugal & 17 & 13 & 12 & 9 & 15 & 11 & 10 & 11 & 13 & 13 & 16 & 16 & Portugal \\
\hline Romania & 5 & 4 & 3 & 3 & 4 & 2 & 2 & 3 & 2 & 2 & 2 & 2 & Romania \\
\hline Slovenia & 8 & 8 & 8 & 13 & 8 & 9 & 11 & 12 & 11 & 9 & 9 & 9 & Slovenia \\
\hline Slovakia & 14 & 12 & 9 & 12 & 12 & 13 & 13 & 14 & 15 & 14 & 11 & 12 & Slovakia \\
\hline Finland & 2 & 6 & 6 & 4 & 5 & 6 & 6 & 5 & 5 & 5 & 4 & 4 & Finland \\
\hline Sweden & 6 & 5 & 2 & 2 & 2 & 7 & 7 & 7 & 7 & 8 & 7 & 8 & Sweden \\
\hline United Kingdom & 24 & 25 & 23 & 23 & 22 & 24 & 22 & 25 & 24 & 23 & 21 & 19 & United Kingdom \\
\hline
\end{tabular}

Source: own study. 
best-classified among the V4 countries. The reverse trend was observed in the other two countries, the Czech Republic ranked 5 positions lower in the general ranking. Poland, meanwhile, dropped from the top to the lowest position in the V4 group.

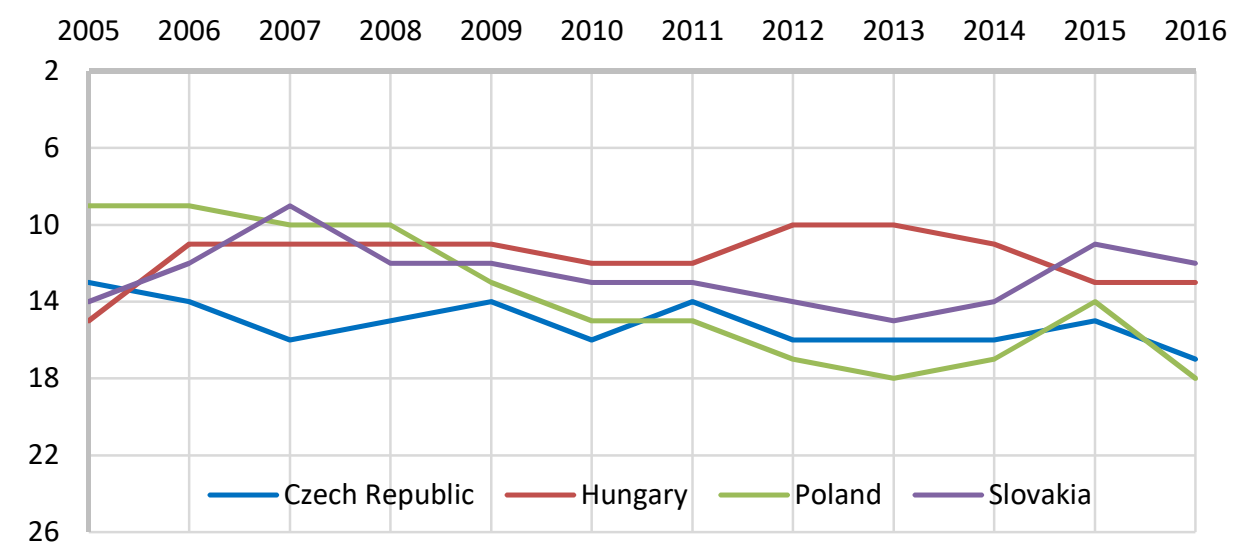

Figure 6. The positions of the V4 countries in the ranking of achieving the 20-20-20 target in the years 2005-2016 Source: own study.

During the research, the positions of individual countries were determined, and the result were presented in Figure 7. The group being studied was divided on the basis of quartiles. This grouping provides an idea of where the results of the V4 economies are positioned against the entire group. Eventually, there emerged three groups of countries in terms of the synthetic value:

1. Countries which are the best in achieving the 20-20-20 target;

2. Countries which are average in achieving the 20-20-20 target;

3. Countries which are the poorest in achieving the 20-20-20 target.

In the period being analysed, the V4 economies are in the second group, i.e. the countries with average results in achieving the 20-20-20 target. This elaboration emphasises the improvement in Slovakia's and Hungary's positions, with a simultaneous worsening of that of Poland and the Czech Republic.

A prediction of the three explanatory variables was prepared, i.e. 'greenhouse gas emission, base year 1990'; 'share of renewable energy in gross final energy consumption'; 'primary energy consumption'. Holt's-Winters' triple exponential smoothing method was used for smoothing the analysed time series, and the results obtained are presented in Table 3.

Despite the long-time EU perspective in reference to the action plan concerning the transition to a low-carbon economy by 2050, and the new 2030 framework for climate and energy, adopted in 2014, the forecast mainly concerns the year 2020. Although the table includes the forecast for 2030, it should be treated with caution because of the long timescale. It is hard to predict the progress results of the V4 countries only on the basis of a linear trend, leaving aside other factors. Therefore, when interpreting the obtained results, we will focus on the year 2020. The outcome of the analyses carried out allows us to state that the 
estimated changes in three V4 countries: the Czech Republic, Hungary, and Slovakia, will enable them to fulfil the objectives of the climate and energy framework by 2020.

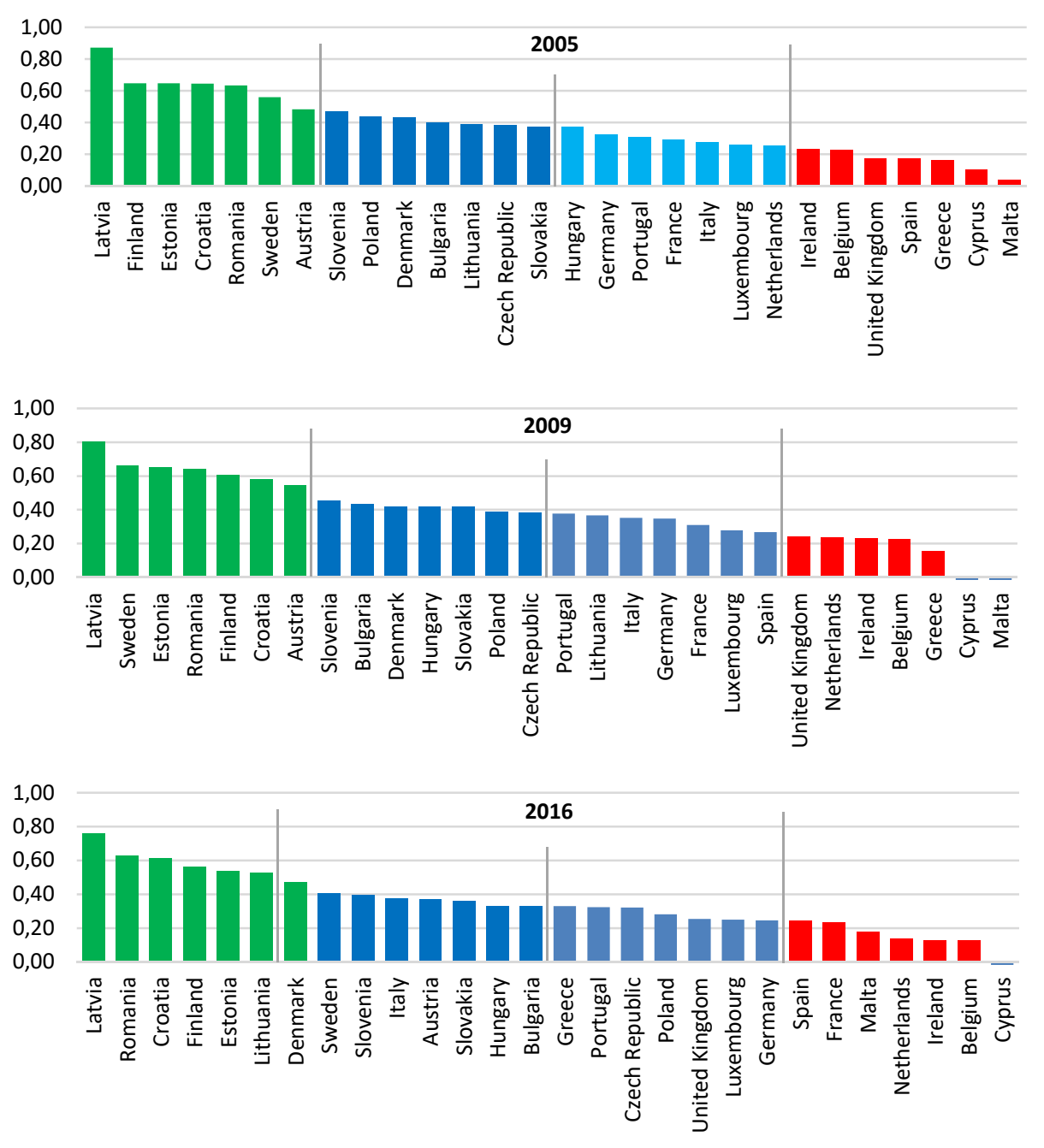

Figure 7. The EU countries divided into typological groups in terms of the synthetic variable value in 2005, 2009 and 2016 Source: own study.

Poland is in the most unfavourable situation of all the economies studied, despite the fact that its primary energy consumption is lower by $2.8 \%$ compared to the target of 96.4 Mtoe. Nevertheless, the estimates concerning the other two features indicate greenhouse gas emissions that will be higher by $2 \%$, and an insufficient share of renewable energy in the consumption structure (here the difference is $0.5 \%$ ). 
Table 3. Projections for 2020 and 2030 with existing measures

\begin{tabular}{|l|c|c|c|c|c|c|c|c|}
\hline \multirow{2}{*}{ 20-20-20 target } & \multicolumn{2}{|c|}{ CZ } & \multicolumn{2}{c|}{ HU } & \multicolumn{2}{c|}{ PL } & \multicolumn{2}{c|}{ SL } \\
\cline { 2 - 9 } & $\mathbf{2 0 2 0}$ & $\mathbf{2 0 3 0}$ & $\mathbf{2 0 2 0}$ & $\mathbf{2 0 3 0}$ & $\mathbf{2 0 2 0}$ & $\mathbf{2 0 3 0}$ & $\mathbf{2 0 2 0}$ & $\mathbf{2 0 3 0}$ \\
\hline $\begin{array}{l}\text { Greenhouse gas emissions, } \\
\text { base year 1990 (\%) }\end{array}$ & 58.6 & 45.3 & 53.7 & 35.9 & 82.0 & 78.5 & 48.0 & 33.2 \\
\hline $\begin{array}{l}\text { Share of renewable energy in gross } \\
\text { final energy consumption (\%) }\end{array}$ & 18.8 & 26.8 & 20.0 & 29.0 & 13.5 & 18.5 & 14.9 & 20.7 \\
\hline $\begin{array}{l}\text { Primary energy consumption } \\
\text { (million tonnes of oil equivalent) }\end{array}$ & 39.5 & 39.1 & 22.9 & 22.0 & 93.6 & 91.9 & 15.1 & 14.2 \\
\hline
\end{tabular}

Source: own study.

\section{CONCLUSIONS}

The EU has set a clear framework establishing the directions of its climate and energy policy towards reducing greenhouse gas emissions, promoting renewable sources of energy, and saving energy consumption. The framework integrates various objectives, including the improvement of the energy security level of the EU member states. This priority is of high importance for the V4 countries, heavily dependent on the import of energy materials. Moreover, the structure of energy consumption in these countries is still dominated by high-carbon conventional sources: the Czech Republic and Poland rely mainly on coal, Hungary - on oil. Slovakia has relatively the most balanced structure of energy material consumption in this group of countries. The data that was collected and analysed indicates the following conclusions in terms of the three explanatory variables that were studied:

- reduction of greenhouse gas emissions: the Czech Republic, Hungary, and Slovakia had already achieved their targets for 2020 in 2016. Poland, on the other hand, exceeded the limit by $5 \%$,

- production of energy from RSE: in 2016, the Czech and the Hungarian economies recorded shares higher than the target (by $1.9 \%$ and $1.2 \%$ respectively). Poland needed to catch up by $3.7 \%$, and Slovakia - by $2.0 \%$,

- energy consumption saving: by 2016, Slovakia, Poland, and Hungary had reduced energy use to the adopted target. Energy consumption in the Czech Republic exceeded the indicated limit by $0.6 \%$ - 39.6 Mtoe.

Despite some progress in implementing the 20-20-20 targets, the research carried out based on the synthetic variable shows that the aggregate measure was lower in 2016 compared with 2005 due to the mean values for the entire EU. Taking into consideration all member states, the V4 economies record an average rate in the implementation of the climate and energy framework. Slovakia and Hungary are ranked the highest in this regard, Poland and the Czech Republic the lowest. The tendencies observed thus represent a large challenge for the hypothesis about the possibility of improving the level of energy security of the V4 countries as a result of the systematic implementation of the energy and climate package. The main motif of the debate on the security of the V4 countries is their dependence on the import of crude oil and gas from Russia, a subject which has been extensively studied by Kovács et al. (2011). The studies carried out so far in the 
context of the challenges connected with the energy security of the V4 countries, concentrated first of all on the bottlenecks in energy infrastructure and infrastructure projects in the region (Siddi, 2016). Such a vision of energy security is definitely caused by the gas crises between Russia and Ukraine from 2006 and 2009, during which the V4 countries suffered a lot. However, in the debate over energy security, it must be stressed that this is a multi-aspect phenomenon which cannot be described with one single definition - see Kruyt et al., (2009), Winzer (2012) and Narula and Reddy (2015). Therefore, it seems that the V4 countries might treat the execution of the energy and climate package not only as a controversial and costly requirement of the EU energy policy - which is underlined by McKillop (2012), but also as a chance to increase this security in its all aspects. The studies carried out for this article show the necessity of the rationalisation of energy consumption and of an increase in the share of renewable sources of energy in the energy mix and the reduction of greenhouse gases in this context.

The forecasted chances of fulfilling the obligations for the year 2020 show that all the economies analysed except Poland will meet the objectives. The forecast for the structure of generation capacity in the V4 countries indicates an increase in the share of renewable energy in total consumption between 2005 and 2020 by $13.1 \%$ in Hungary, $11.7 \%$ in the Czech Republic, $8.5 \%$ in Slovakia, and $6.6 \%$ in Poland. Nevertheless, the improvement in the last two countries is not sufficient to meet the framework guidelines in this respect. However, as far as energy efficiency improvement is concerned, based on the predictions for the year 2020, we can indicate a reduction of energy consumption by $3 \%$ in the Czech and Hungarian economies, and by $2.7 \%$ in Slovakia compared to 2005 . For Poland, however, a result worse by $5.9 \%$ is estimated, but even this enables the country to meet its reduction objective adopted in the framework. Therefore, it is necessary in these economies, and especially in Poland, to promote and support a number of initiatives aimed at, among other things, developing Clean Coal Technology, increasing the share of eco-fuels in transport, modernising the construction sector, developing low-carbon energy sources, etc. These actions are of crucial importance as the total abandonment of coal is currently impossible in Poland's energy mix. The worrying results of these studies concerning Poland's execution of the objectives of the energy and climate package, against the background of the remaining V4 countries, will become an inspiration for the Authors to take up, in the future, research aimed at the identification of the causes of this situation in Poland. Furthermore, the research period ends in 2016 with respect to the availability of the statistical data, yet it is worthwhile to observe that similar studies should be re-initiated, especially with regards to the end of the 2020 perspective.

\section{REFERENCES}

Augutis, J., Krikstolaitis, J., Martisauskas, L., \& Peciulyte, S. (2012). Energy security level assessment technology. Applied Energy, 97, 143-149. https://doi.org/10.1016/j.apenergy.2011.11.032

Chalvatzis, K., \& loannidis, A. (2017). Energy supply security in the EU: Benchmarking diversity and dependence of primary energy. Applied Energy, 207, 465-476. https://doi.org/10.1016/j.apenergy.2017.07.010

Cherp, A., \& Jewel, J. (2011). The three perspectives on energy security: intellectual history, disciplinary roots and the potential for integration. Current Opinion in Environmental Sustainability, 3(4), 202-221. https://doi.org/10.1016/j.cosust.2011.07.001 
Chester, L. (2010). Conceptualising energy security and making explicit its polysemic nature. Energy Policy, 38(2), 887-895. https://doi.org/10.1016/j.enpol.2009.10.039

Cipollaro, A., \& Lomonaco, G. (2016). Contributing to the nuclear 3S's via a methodology aiming at enhancing the synergies between nuclear security and safety. Progress in Nuclear. Energy, 86, 31-39. https://doi.org/10.1016/j.pnucene.2015.09.013

Costantini, V., Gracceva, F., Markandya, A., \& Vicini, G. (2006). Security of energy supply: comparing scenarios from a European perspective. Energy Policy, 35, 210-226. https://doi.org/10.1016/j.enpol.2005.11.002

Czech, A. (2017). Economic dimension of Polish energy security. Oeconomia Copernicana, 8(3), 383399. https://doi.org/10.24136/oc.v8i3.24

Dannreuhter, R. (2017). Energy security. Polity Press, 10-25.

Dyer, H., \& Trombetta, M.J. (2013). The concept of energy security: broadening, deepening transforming. International handbook of energy security (pp. 3-18). Northampton, USA: Edward Elgar Publishing Limited.

Eikeland, P.O. (2014). Implementing the EU 2020. Energy and Climate Package in Germany. FNI Reports. 12/30/2014, preceding, 1-101. Retrieved on December, 2018 from https://www.fni.no/publications/implementing-the-eu-2020-energy-and-climate-package-ingermany-green-champion-struggling-to-adapt-article875-290.html

European Commission. (2010). Communication from the Commission. Europe 2020, A strategy for smart, sustainable and inclusive growth, Brussels, 3.3.2010, $\operatorname{COM(2010)~2020.~Retrieved~from~http://eur-~}$ lex.europa.eu/LexUriServ/LexUriServ.do?uri=COM:2010: 2020:FIN:EN:PDF on December 10, 2018.

European Commission. (2012). Directive 2012/27/EU of the European Parliament and of the Council of 25 October 2012 on energy efficiency, amending Directives 2009/125/EC and 2010/30/EU and repealing Directives 2004/8/EC and 2006/32/EC Text with EEA relevance, OJ L 315, 14.11.2012, 156. Retrieved from: http://data.europa.eu/eli/dir/2012/27/oj on December 10, 2018.

European Commission. (2013). Council Directive 2013/12/EU of 13 May 2013 adapting Directive 2012/27/EU of the European Parliament and of the Council on energy efficiency, by reason of the accession of the Republic of Croatia, OJ L 141, 28.5.2013, 28-29. Retrieved from https://eurlex.europa.eu/legal-content/EN/TXT/?uri=celex\%3A32013L0012 on December 10, 2018.

European Commission. (2018). Energy Statistical Pocketbook. Luxembourg: Publications Office of European Union, 24-26. Retrieved from https://publications.europa.eu/en/ publication-detail//publication/99fc30eb-c06d-11e8-9893-01aa75ed71a1/language-en on December 10, 2018.

European Parliament and the Council of the European Union. (2009). Decision No 406/2009/EC of the European Parliament and the Council of the European Union of 23 April 2009 on the effort of Member States to reduce their greenhouse gas emissions to meet the Community's greenhouse gas emission reduction commitments up to 2020 (OJ L 140/136), 06.2009. Retrieved from https://eur-lex.europa.eu/eli/dec/2009/406/oj on December 10, 2018.

Eurostat. Europe 2020 indicators - climate change and energy. Retrieved from https://ec.europa.eu/ eurostat/statistics-explained/index.php/Europe_2020_indicators_-_climate_change_and_energy on December 10, 2018.

Finon, D., \& Locatelli, C. (2008). Russian and European gas interdependence: Could contractual trade channel geopolitics?. Energy Policy, 36(1), 423 -442. https://doi.org/10.1016/j.enpol.2007.08.038

Fitzmaurice, J. (1998). Politics and Government in the Visegrad Countries: Poland, Hungary, the Czech Republic and Slovakia (pp. 21-23). Macmillan Press.

Gałecka, M., \& Smolny, K. (2018). Evolution of Theater Activity Using Hellwig's method. Optimus. Economic Srudies. 2(92), 38-50. https://doi.org/10.15290/oes.2018.02.92.04 
Gálová, J. (2013). Opportunities for Doing Business with Countries Neighbouring V4 The Case of Ukraine'. Entrepreneurial Business and Economics Review, 1(1), 77-90. https://doi.org/ 10.15678/EBER.2013.010106

Goldthau, A. (2011). Governing global energy: existing approaches and discourses. Current Opinion in Environmental Sustainability, 3(4), 213-217. https://doi.org/10.1016/j.cosust.2011.06.003

Goldthau, A., \& Boersma, T. (2014). The 2014 Ukraine-Russia crisis: Implications for energy markets and scholarship. Energy Research \& Social Science, 3, 13-15. https://doi.org/10.1016/j.erss.2014.05.001

Gulbrandsen, L., \& Skjærseth, J.B. (2014). Implementing the EU 2020 Climate and Energy Package in the Netherlands. Mixed Instruments, Mixed Results. FNI Reports. 12/15/2014, preceding 1-46. Retrieved from https://www.fni.no/publications/implementing-the-eu-2020-climate-and-energy-package-inthe-netherlands-mixed-instruments-mixed-results-article876-290.html on December 10, 2018.

Gunnar Austvik, O. (2016). The Energy Union and security-of-gas supply. Energy Policy, 96, 372-382. https://doi.org/10.1016/j.enpol.2016.06.013

Helm, D. (2014). European framework for energy and climate policies, Energy Policy, 64, 29-35. https://doi.org/10.1016/j.enpol.2013.05.063

Henriksen, C.B, Hussey, K., \& Holm, P. (2011). Exploiting Soil-Management Strategies for Climate Mitigation in the European Union: Maximizing 'Win-Win' Solutions across Policy Regimes. Ecology \& Society. 2011, 16(4), 1-17. https://doi.org/ 10.5751/ES-04176-160422

International Energy Agency. (2007). World Energy Outlook 2007, Paris 2007, 161-162. Retrieved from:https://www.iea.org/publications/freepublications/publication/weo2007.pdf on December 10, 2018.

International Energy Agency. (2018). What is energy security. Retrieved from https://www.iea.org/topics/energysecurity/whatisenergysecurity/ on February 15, 2019.

Jääskeläinen, J., Höysniemi, S., Syri S., \& Tynkkynen, V.P. (2018). Finland's Dependence on Russian Energy-Mutually Beneficial Trade Relations or an Energy Security Threat. Sustainability, 10, 125. https://doi.org/10.3390/su10103445

Jamasb, T., \& Pollit, M. (2008). Security of supply and regulation of energy networks. Energy Policy, 36(12), 4584-4589. https://doi.org/10.1016/j.enpol.2008.09.007

Kapustová, Z., Kapusta, J., \& Bielik, P. (2018). Food-biofuels interactions: The case of the U.S. biofuels market. Agris On-line Papers in Economics and Informatics 10(4), 27-38.

Kiriyama, E., \& Kajikawa, Y. (2014). A multilayered analysis of energy security research and the energy supply process. Applied Energy, 123, 415-423. https://doi.org/10.1016/j.apenergy.2014.01.026

Kovács, P., Szczerski, K., Binhack, P., Farkas, M., Jaroš, J., Kołaczkowski, M., Ruszel, M., Szlagowski, P., Szolnoki, E., Ševce, P., \& Albrycht, I. (2011). Energy security of the V4 countries. How do energy relations change in Europe. The Kosciuszko Institute. Retrieved from http://www.pssi.cz/download/docs/117_energy-security-of-the-v4-countries.pdf on February 15, 2019.

Kruyt, B., van Vuuren, D.P., de Vries, H.J.M., \& Groenenberg, H. (2009). Indicators for energy security. Energy Policy, 37, 2166-2181. https://doi.org/10.1016/j.enpol.2009.02.006

Lee, Y. (2017). Interdependence, issue importance, and the 2009 Russia-Ukraine gas conflict. Energy Policy. 102, 199-209. https://doi.org/10.1016/j.enpol.2016.11.038

Love, T.F., Rupp, S., \& Strauss, S. (2013). Cultures of Energy: Power, Practices, Technologies. The Australian Journal of Anthropology, 27(3), 1-60. https://doi.org/10.1111/taja.12212

Löschel, A., Moslener, U., \& Rübbelke, D. (2010). Indicators of energy security in industrialised countries. Energy Policy, 38(4), 1665-1671. https://doi.org/10.1016/j.enpol.2009.03.061 
Månsson, A., Johansson, B., \& Nilsson, L. (2014). Assessing energy security: An overview of commonly usedmethodologies. Energy, 73(14), 1-14. https://doi.org/10.1016/j.energy.2014.06.073

Månsson, A. (2014). Energy, conflict and war: towards a conceptual framework. Energy Research and Social Science, 4, 106-116. https://doi.org/10.1016/j.erss.2014.10.004

Markandya, A., \& Pemberton, M. (2010). Energy security, energy modelling and uncertainty. Energy Policy, 38(4), 1609-1613. https://doi.org/10.1016/j.enpol.2009.01.046

Marquina, A. (2008). Energy Security. Visions from Asia and Europe. Basingstoke (pp. 34-53), New York: Palgrave Macmillan.

McKillop, A. (2012). Europe's Climate Energy Package Must Be Reformed or Abandoned. Energy \& Environment, 23(5), 837-848. https://doi.org/10.1260/0958-305X.23.5.837

Mitchell, V., \& Moudgill, P. (1976). Measurement of Maslow's Need Hierarchy. Organizational Behavior and Human Performance, 16(2), 334-349. https://doi.org/10.1016/0030-5073(76)90020-9

Narula, K., \& Reddy, B. (2015). Three blind men and an elephant: The case of energy indices to measure energy security and energy sustainability. Energy, 80, 148-158. https://doi.org/10.1016/j.energy.2014.11.055

Nyga-Łukaszewska, H., \& Chilimoniuk-Przeździecka, E. (2017). Modelling Energy Security and International Competitiveness: The Export Perspective. Entrepreneurial Business and Economics Review, 5(2), 71-84. https://doi.org/10.15678/EBER.2017.050204

Pach-Gurgul, A. (2016). Europeanisation of Energy Policy: Progress in Spite of Divergent Interest. In P. Stanek \& K. Wach (Eds.), Macro-, Meso-, and Microeconomic Dimensions of Europeanisation (pp. 141-164). Warsaw: PWN.

Proskuryakova, L. (2018). Updating energy security and environmental policy: Energy security theories revisited. Journal of Environmental Management, 223(2018), 203-214. https://doi.org/10.1016/j.jenvman.2018.06.016

Pach-Gurgul, A. (2018). The Possibilities of Gas and Oil Export to the Visegrad Group Countries in the Context of CETA. In Proceedings of the 18th International Joint Conference Central and Eastern Europe in the Changing Business Environment, (pp. 308-319). Prague: Oeconomica Publishing House, University of Economics.

Radovanovića, M., Filipović, S., \& Pavlovićc, D. (2017). Energy security measurement - A sustainable approach. Renewable and Sustainable Energy Reviews, 68(2017), 1020-1032. https://doi.org/10.1016/j.rser.2016.02.010

Semenenko, I. (2016). Energy security of Ukraine in the context of its sustainable development. Equilibrium. Quarterly Journal of Economics and Economic Policy, 11(3), 537-555. https://doi.org/10.12775/EQUIL.2016.024

Siddi, M. (2016). The EU's Energy Union: A Sustainable Path to Energy Security?. The International Spectator. 51(1), 131-144. https://doi.org/:10.1080/03932729.2016.1090827

Simanaviciene, Z., Volochovic, A., \& Cibinskiene, A. (2016). Features of energy saving potential in Lithuanian households. Equilibrium. Quarterly Journal of Economics and Economic Policy, 11(1), 145-157. https://doi.org/10.12775/EQUIL.2016.007

Slaboch, J., \& Hálová, P. (2016). The influence of investment costs on biogas station development and their impact on greenhouse gas emissions from czech agriculture. Agris On-line Papers in Economics and Informatics 8(4), 143-151.

Sojka, E. (2018). Poland in socio-economic development ranking of the EU countries. In W. Szkutnik, A. Sączewska-Piotrowska, M. Hadaś-Dyduch, \& J. Acedański (Eds.). 9th International Scientific 
Conference Analysis of International Relations 2018. Methods and Models of Regional Development. Winter Edition. Conference Proceedings (pp. 130-139). Katowice: Publishing House of the University of Economics in Katowice.

Sovacool, B., Mukherjee, I., Drupady, I., \& D’Agostino, A. (2011). Evaluating energy security performance from 1990 to 2010 for eighteen countries' Energy. 36(10), 5846-5853. https://doi.org/10.1016/j.energy.2011.08.040

Sovacool, B.K. (2013). An international assessment of energy security performance. Ecological Economics, 88, 148-158. https://doi.org/10.1016/j.ecolecon.2013.01.019

Stephenson, J., Barton, B., Carrington, G., Gnoth, D., Lawson, R., \& Thorsnes, P. (2010). Energy Cultures: A framework for understanding energy behaviours. Energy Policy, 38, 6120-6129. https://doi.org/10.1016/j.enpol.2010.05.069

Śmiech, S., \& Papież, M. (2014). Energy Consumption and Economic Growth in the Light of Meeting the Targets of Energy Policy in the EU: The Bootstrap Panel Granger Causality Approach. Energy Policy, 71, 118-29. https://doi.org/10.1016/j.enpol.2014.04.005

Tapio, T., Banister, D., Luukkanen, J., Vehmas, J., \& Willamo, R. (2007). Energy and Transport in Comparison: Immaterialisation, Dematerialization and Decarbonisation in the EU 15 between 1970 and 2000. Energy Policy, 35, 433-451. https://doi.org/10.1016/j.enpol.2005.11.031

Ulbrych, M. (2016). Europeanisation of Industrial Policy: Towards a Re-Industrialisation of Europe. In P. Stanek \& K. Wach (Eds.), Macro-, Meso-, and Microeconomic Dimensions of Europeanisation (pp. 121-140). Warsaw: PWN.

Ulbrych, M. (2018). The Role and Importance of Manufacturing Trade Cooperation of the Visegrad. In Proceedings of the 18th International Joint Conference Central and Eastern Europe in the Changing Business Environment. Prague: Oeconomica Publishing House, University of Economics.

Uusi-Rauva, Ch. (2010). The EU energy and climate package: a showcase for European environmental leadership?. Environmental Policy and Governance, 20(2), 73-88. https://doi.org/10.1002/eet.535

Van de Graaf, T., \& Colgan, J. (2017). Russian gas games or well-oiled conflict? Energy security and the 2014. Ukraine crisis. Energy Research \& Social Science, 24, 59-64, https://doi.org/10.1016/j.erss.2016.12.01

Xia, X.H., Huang, G.T., Chen, G.Q., Zhang, B., Chen, Z.M., \& Yang, Q. (2011). Energy security, efficiency and carbon emission of Chinese industry. Energy Policy, 39(6), 3520-3528. https://doi.org/10.1016/j.enpol.2011.03.051

Yergin, D. (2006). Ensuring Energy Security. Foreign Affairs, 85(2), 70-71.

Wang, B., Wang, Q., Wei, Y.-M., \& Li, Z.-P. (2018). Role of renewable energy in China's energy security and climate change mitigation: an index decomposition analysis. Renewables Sustainability Energy Review, 90, 187-194. https://doi.org/10.1016/j.rser.2018.03.012

Winzer, Ch. (2012). Conceptualizing Energy Security. Energy Policy, 46, 36-48. https://doi.org/10.1016/j.enpol.2012.02.067

Zajączkowska, M. (2016). Prospects for the development of prosumer energy in Poland. Oeconomia Copernicana, 7(3), 439-449. https://doi.org/10.12775/OeC.2016.025

Zhou, W., Kou, A., Chen, J., \& Ding, B. (2018). A retrospective analysis with bibliometric of energy security in 2000- 2017. Energy Reports, 4, 724-732, https://doi.org/10.1016/j.egyr.2018.10.01 


\section{Authors}

The contribution share of authors is equal and amounted to $50 \%$ each of them.

\section{Agnieszka Pach-Gurgul}

Master in Economics (Faculty of Economics, specialisation: World Economy, Cracow University of Economics); PhD in Economics (Cracow University of Economics). Her research interests include EU energy policy, energy security, sustainable development, climate policy, international commodity markets.

Correspondence to: Agnieszka Pach-Gurgul, PhD, International Economics Department, Cracow University of Economics, ul. Rakowicka 27, 31-510 Kraków, Poland, e-mail: apach@uek.krakow.pl ORCID (1) http://orcid.org/0000-0003-1917-4679

\section{Marta Ulbrych}

Master in Economics (Faculty of Economics, specialisation: Foreign Trade, Cracow University of Economics); PhD in Economics (Cracow University of Economics). Her research interests include the theory and practice of international economic integration and the role of industry/manufacturing and industrial policy in the globalisation era.

Correspondence to: Marta Ulbrych, PhD, International Economics Department, Cracow University of Economics, ul. Rakowicka 27, 31-510 Kraków, Poland, e-mail: ulbrychm@uek.krakow.pl ORCID $₫$ http://orcid.org/0000-0003-3886-371X

\section{Acknowledgements and Financial Disclosure}

This publication received financial support from the resources granted to the Faculty of Economics and International Relations of the Cracow University of Economics as part of the subsidy for the maintenance of the research potential.

This article has been presented as the academic paper at the scientific conference GLOB2018: "Globalization and Regionalization in the Contemporary World: Competitiveness, Development, Sustainability" organized in Kraków on 21-22 September 2019.

\section{Copyright and License}

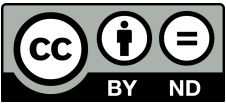

This article is published under the terms of the Creative Commons

Attribution - NoDerivs (CC BY-ND 4.0) License

http://creativecommons.org/licenses/by-nd/4.0/

\section{Published by the Centre for Strategic and International Entrepreneurship - Krakow, Poland}

Ministry of Science and Higher Education Republic of Poland
The copyediting and proofreading of articles in English is financed in the framework of contract No. 913/P-DUN/2019 by the Ministry of Science and Higher Education of the Republic of Poland committed to activities aimed at science promotion.

This publication has been co-financed by the European Commission Representation in Poland. The European Commission, or any person acting on its behalf, is not responsible for the use of the information contained in this publication. This publication reflects the views only of the authors, and the European Commission cannot be held responsible for any use which may be made of the information contained therein. 
